\title{
The Undrained Behaviour of an Air-Fall Volcanic Ash
}

\author{
Luciano Picarelli ${ }^{1}$, Lucio Olivares ${ }^{1, *}$, , Salvatore Lampitiello ${ }^{2}$, Reza Darban ${ }^{1}$ and \\ Emilia Damiano ${ }^{1}$ \\ 1 Department of Engineering, University of Campania "Luigi Vanvitelli", 81031 Aversa, Italy; \\ luciano.picarelli@unicampania.it (L.P.); reza.darban@unicampania.it (R.D.); \\ emilia.damiano@unicampania.it (E.D.) \\ 2 Freelance Professional, 81031 Aversa, Italy; Inglampitiello@gmail.com \\ * Correspondence: lucio.olivares@unicampania.it
}

Received: 31 December 2019; Accepted: 30 January 2020; Published: 5 February 2020

check for updates

\begin{abstract}
Pyroclastic soils are widespread in the world. In particular, they cover a great part of Campania, a densely populated country of Southern Italy, where some distinct volcanic centers are present. In these soils, precipitations can trigger fast flow-like landslides causing destruction and loss of human lives. The movement style, the high velocity and the long run-out of these landslides are an indication of the occurrence, in the saturated soil mass, of mechanisms of undrained instability due to the inability of soil to sustain the deviator stress related to the slope condition. This paper reports the results of a wide experimental laboratory program carried out on a volcanic ash, which recently has been the seat of a killer landslide, stressing the factors that govern the undrained response of these materials.
\end{abstract}

Keywords: volcanic ash; undrained shear strength; soil liquefaction; landslide

\section{Foreword}

Recent literature has widely documented the features of sudden and destructive fast flow-like landslides, which are induced by precipitations or even by irrigation in unsaturated non-plastic granular soils [1-3]. Based on field and laboratory investigations, agreement has been established around the idea that such catastrophic events are due to a mechanical chain process characterized by saturation increase due to rainwater infiltration, corresponding reduction of shear strength, volumetric collapse and, near saturation, and undrained instability induced by building up of excess pore pressures [4-7]. Furthermore, it has been shown that it is possible, by distinguishing the gentle slopes from the steep and very steep slopes, to explain the catastrophic flow-like landslides that periodically occur in the volcanic ash deposits (Figure 1a), which mantle hills and mountains in the Campania Region, Southern Italy [8-10]. In spite of that, most of the research until now has been addressed towards the characterization of the mechanical and hydraulic properties of the soil in unsaturated conditions. Conversely, this research is aimed at characterizing the soil behavior in saturated conditions.

The paper reports the results of a campaign of undrained triaxial tests on saturated specimens of air-fall volcanic ash, which in 1999 was involved in a catastrophic flowslide causing huge damage in Cervinara town located just at the foot of the mountain (Figure 1b,c). The experimental program focuses on the role that stress history, stress path and void ratio play on the undrained strength of these materials. 

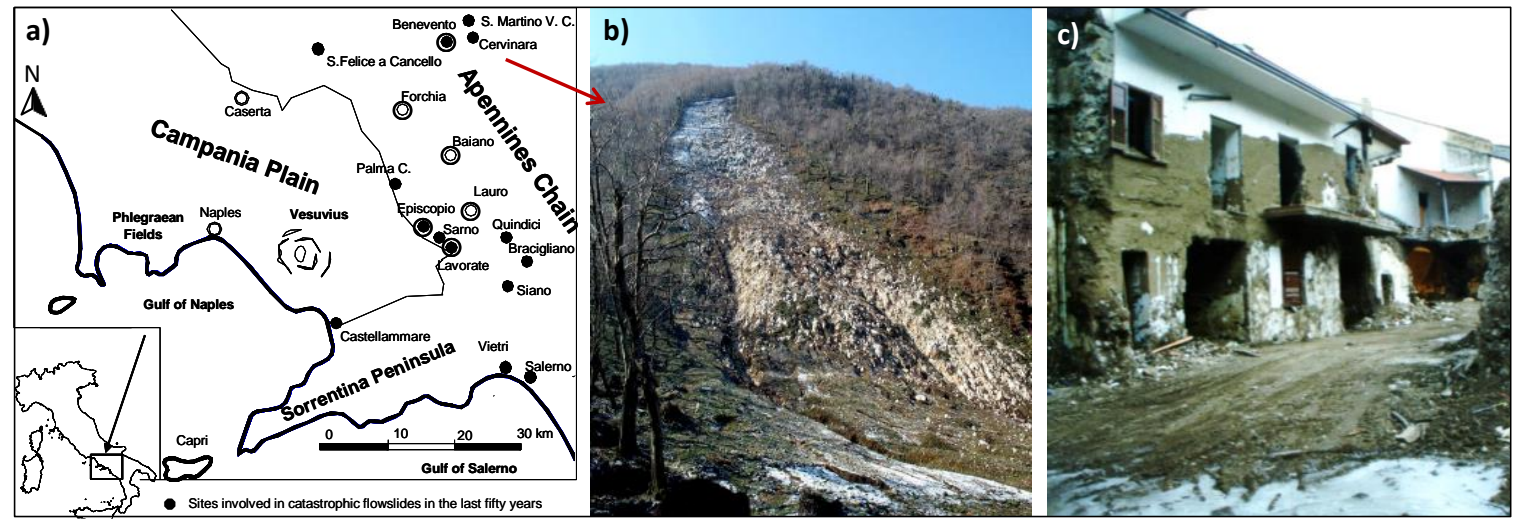

Figure 1. (a) Location of Cervinara and other sites subjected to flow-like landslides; (b) the Cervinara flowslide; (c) some effects of the landslide in the town.

\section{General Features of Air-Fall Volcanic Ashes in Campania}

Air-fall volcanic ashes cover a large part of Campania. Primary sloping deposits are generally unsaturated and shallow (their depth does not exceed 2-3 m). The cohesive intercept due to suction then plays a key role on the stability of slopes, which may present angles up to $50^{\circ}$, much higher than the saturated friction angles of the soils. For this reason precipitations, which strongly affect suction through rainwater infiltration, are a major trigger of landslides.

These geologically young materials may be classified as non-plastic silty sands (Figure 2). A peculiar feature of them is the high void ratio. In fact, all available data regarding deposits present at different sites located even tens of kilometers apart range between a minimum value of 1.8 up to 2.8 and more [11]: the values that have been measured on the Cervinara ash fall in the interval 2.1-2.8. Interestingly, a high void ratio is a peculiarity of air-fall ashes that are present in any part of the world, especially in tropical countries where $60 \%$ of soil deposits have a volcanic origin [12].

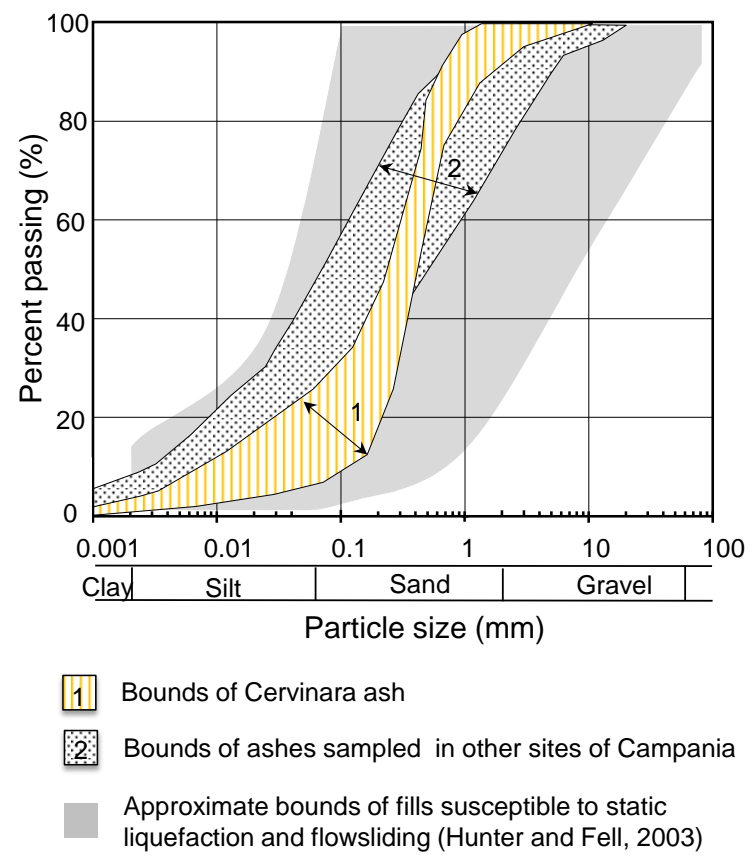

Figure 2. The grain size of eight different deposits of air-fall volcanic ashes in Campania.

Through scanning electron microscopy (SEM) micrographs of samples of the Cervinara ash, Lampitiello [13] showed that the sandy grains are coated by silty particles, which form a sort of "adhering 
dust"; moreover, chains of these fine particles can bridge the coarsest particles. The combination of these features leads to a highly collapsible microfabric, which is fully revealed by the effects of loading and of saturation.

However, due to the size and sharp edges of the sandy particles, these completely unbounded cohesionless soils present quite a high friction angle. All data collected in the past on air-fall ashes from most of the sites indicated in Figure 1a, show that the friction angle is seldom less than $34^{\circ}$, attaining values up to $39^{\circ}[14,15]$. Values of $38-39^{\circ}$ also characterize the Cervinara ash. Accounting for the high void ratio of the material, such values correspond to the steady-state, or critical, friction angle.

In spite of the high frictional strength, these air-fall volcanic ashes often display a low undrained strength at high strains due to the building up of high positive excess pore pressures. The mechanical process leading to such a drop in deviator stress is generally referred to as undrained instability or, more simply, liquefaction. This mostly depends on grain size and void ratio. As a matter of fact, Hunter and Fell [16] show that the soils which are susceptible to liquefaction generally occupy the domain of sands and of non-plastic silts, which is the same grain size of the air-fall volcanic ashes present in Campania [11] (Figure 2). The second key factor which governs the susceptibility of soil to liquefaction is void ratio, $e$. In fact, the mechanism of undrained instability can take place only in soils having a void ratio located above the steady-state line (SSL) in the compression plane $\left(e, \log p^{\prime}\right)$ : as higher is the void ratio as higher the susceptibility to liquefaction. Both factors, grain size and void ratio, in conjunction with the low effective state of stress which characterizes the shallow pyroclastic covers, allow classification of the air-fall volcanic ashes present in Campania in the category of liquefiable materials [17,18].

Figure 3, which summarizes in the stress plane $\left(q, p^{\prime}\right)$ the results of undrained compressions triaxial tests on undisturbed specimens having a void ratio higher than 2.0 retrieved from six different sites [11], is quite clear about that. The figure also shows that all specimens attain their peak strength well before reaching the SSL, then they undergo a continuous drop in deviatoric stress moving along the SSL. However, due to the high excess pore pressure induced by shear, the ultimate undrained strength may be much lower than the peak value, even though the mobilized (steady-state) friction angle is quite high. These considerations will be resumed and commented in the following section.

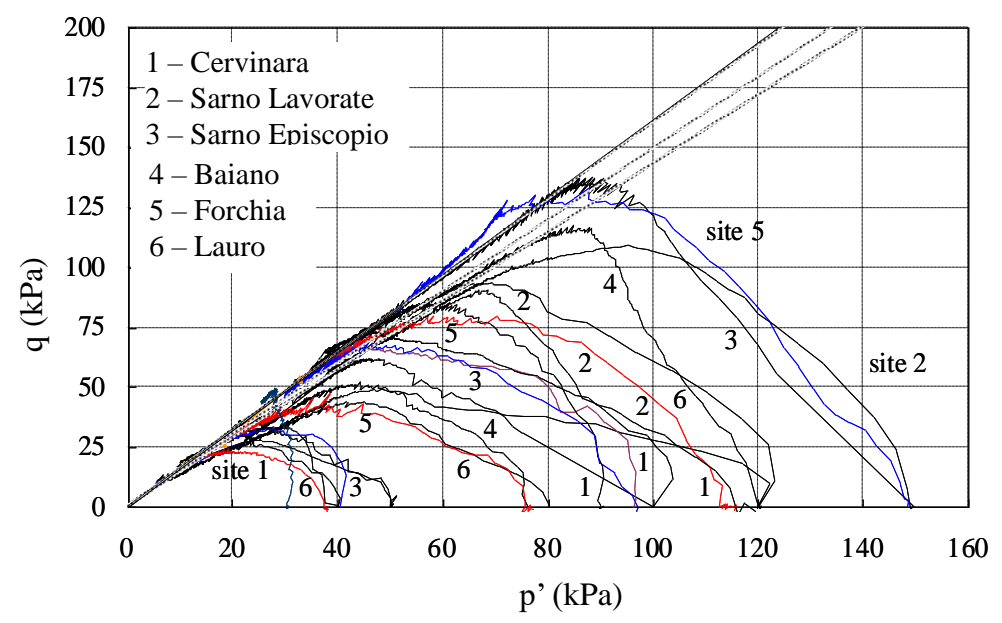

Figure 3. Results of undrained triaxial compression tests on undisturbed specimens of saturated air-fall volcanic ashes from six different sites in Campania.

\section{An Investigation on the Undrained Strength of the Cervinara Volcanic Ash}

This section reports the results of a campaign of undrained triaxial tests on reconstituted specimens of the Cervinara volcanic ash. In the following, first, the procedures adopted in the experimental program are described, then the tests results are illustrated. 


\subsection{Materials and Methods}

Cervinara ash is a silty sand with $10-20 \%$ of non-plastic fine-grained content (Figure 2) and an average diameter of grains, $D_{50}$, of $0.55 \mathrm{~mm}$. The specific weight $\mathrm{G}_{\mathrm{S}}$ is 2.61 ; and the uniformity coefficient $\mathrm{C}$ (ratio $\mathrm{D}_{60} / \mathrm{D}_{10}$ ) is 22 .

The experimental program focused on the influence of void ratio, stress history and stress-path on the undrained soil strength. The specimens, having a diameter of $38 \mathrm{~mm}$ and a height of $76 \mathrm{~mm}$, were prepared by the moist-tamping technique [19] with initial saturation degrees, $S_{r}$, and water contents, $w$, ranging respectively between $28 \%-82 \%$ and $0.19-0.57$ as reported in Table 1 . Full saturation was imposed by flushing the soil, first with $\mathrm{CO}_{2}$, then with de-aired water, until the attainment of a Skempton's pore pressure coefficient, B, higher than 95\%. According to ASTM D4767 (ASTM 2002), the maximum shearing rate imposed in the tests was always less than $0.9 \% / \mathrm{h}$.

Table 1. Experimental program.

\begin{tabular}{|c|c|c|c|c|c|c|c|c|}
\hline \multirow{2}{*}{$\begin{array}{c}\text { Type of } \\
\text { Test }\end{array}$} & \multirow[b]{2}{*}{$\begin{array}{l}\text { Number } \\
\text { of Tests }\end{array}$} & \multirow[b]{2}{*}{$\begin{array}{c}\text { Stress-Path to } \\
\text { Failure }\end{array}$} & \multicolumn{3}{|c|}{ Initial Conditions } & \multicolumn{3}{|c|}{ End of Consolidation } \\
\hline & & & $\operatorname{Sr}(\%)$ & $\mathbf{w}$ & $\mathbf{e}_{0}$ & e & $\mathbf{p}_{0}^{\prime}(\mathbf{k P a})$ & $\mathbf{K}$ \\
\hline \multirow{7}{*}{ CIU_c } & 7 & Compression & $33-65$ & $0.19-0.31$ & $1.19-1.55$ & $1.20-1.46$ & $30-100$ & 1.0 \\
\hline & 7 & Compression & $39-86$ & $0.27-0.50$ & $1.45-1.88$ & $1.40-1.50$ & $30-120$ & 1.0 \\
\hline & 6 & Compression & $45-81$ & $0.29-0.50$ & $1.67-1.72$ & $1.50-1.60$ & $50-150$ & 1.0 \\
\hline & 8 & Compression & $50-72$ & $0.32-0.57$ & $1.68-1.93$ & $1.60-1.70$ & $60-180$ & 1.0 \\
\hline & 5 & Compression & $65-76$ & $0.48-0.50$ & $1.74-2.0$ & $1.70-1.85$ & $30-80$ & 1.0 \\
\hline & 3 & Compression & $50-59$ & $0.39-0.48$ & $2.09-2.14$ & $>1.80$ & $25-60$ & 1.0 \\
\hline & 1 & Extension & 40 & 0.35 & 2.25 & $1.50-1.60$ & 75 & 1.0 \\
\hline \multirow[t]{2}{*}{ CIU_e } & 4 & Extension & $35-40$ & $0.31-0.36$ & $2.24-2.30$ & $1.60-1.70$ & $50-200$ & 1.0 \\
\hline & 5 & Extension & $34-38$ & $0.30-0.34$ & $2.21-2.30$ & $1.70-1.80$ & $40-175$ & 1.0 \\
\hline \multirow{3}{*}{ CAU_c } & 5 & Compression & $29-72$ & $0.19-0.51$ & $1.72-1.88$ & $1.60-1.70$ & $35-180$ & $0.41-0.85$ \\
\hline & 10 & Compression & $28-54$ & $0.19-0.38$ & $1.72-1.95$ & $1.70-1.80$ & $30-140$ & $0.30-0.87$ \\
\hline & 7 & Compression & $43-56$ & $0.31-0.41$ & $1.91-2.08$ & $>1.80$ & 40-90 & $0.33-0.54$ \\
\hline
\end{tabular}

The first part of the program (Table 1) consisted in triaxial compression tests on isotropically (CIU_c) and anisotropically consolidated specimens (CAU_c) prepared at six different ranges of the void ratio. In the CAU tests, different values of the stress ratio, $K$, between the radial and the axial effective stress, were adopted. The second part of the program consisted in extension triaxial tests on isotropically consolidated specimens (CIU_e in Table 1): these tests were carried out by decreasing the axial stress by a strain-controlled procedure, until soil failure. In this case the specimens were prepared at different values of the void ratio too. All experiments were carried out through a Bishop triaxial cell.

As shown in Table 1 , the specimens were initially reconstituted at an initial void ratio, $e_{0}$, ranging between 1.2 and 2.3, then they were consolidated at mean effective pressures, $\mathrm{p}^{\prime}$, between 25 and $200 \mathrm{kPa}$. The values of the void ratio after consolidation comprised between 1.2 and 1.85. It has to be noted that the experimental program covered quite low values of the consolidation pressure $p^{\prime}$ $(25-60 \mathrm{kPa})$ and high void ratios $\left(e_{0}>1.9\right)$ in order to investigate the soil behavior in the range of typical field values.

\subsection{Experimental Results and Interpretation}

The results of all CIU_c tests are shown in Figure 4. In particular, Figure 4a reports in the $q, p^{\prime}$ plane, the stress paths of all tests conducted on specimens displaying an unstable (brittle) behavior, while Figure $4 \mathrm{~b}$ reports the stress paths of specimens with a stable (ductile) response. The legend indicates the void ratio attained at the end of the consolidation stage.

The figure shows that all specimens having a void ratio less than 1.5 , for an effective consolidation pressure ranging in the interval 30-100 kPa (Figure 4b), display a ductile response characterized by a monotonic increase of the deviator stress. For higher values of $e$ (Figure $4 \mathrm{a}$ ), there is a transition towards a brittle response due to generation of excess pore pressures: after having reached a peak, the 
soil cannot sustain the deviator stress which progressively reduces until the reaching of the steady state condition which is represented by a practically unique straight line, the SSL, regardless of the initial soil state. The slope, $M$, of the SSL is about 1.56 , which corresponds to a friction angle of $38^{\circ}$. It is worth mentioning that these results are very consistent with those, reported in Figure 3, obtained on undisturbed specimens, sampled at different sites, which present a natural void ratio higher than 1.8.
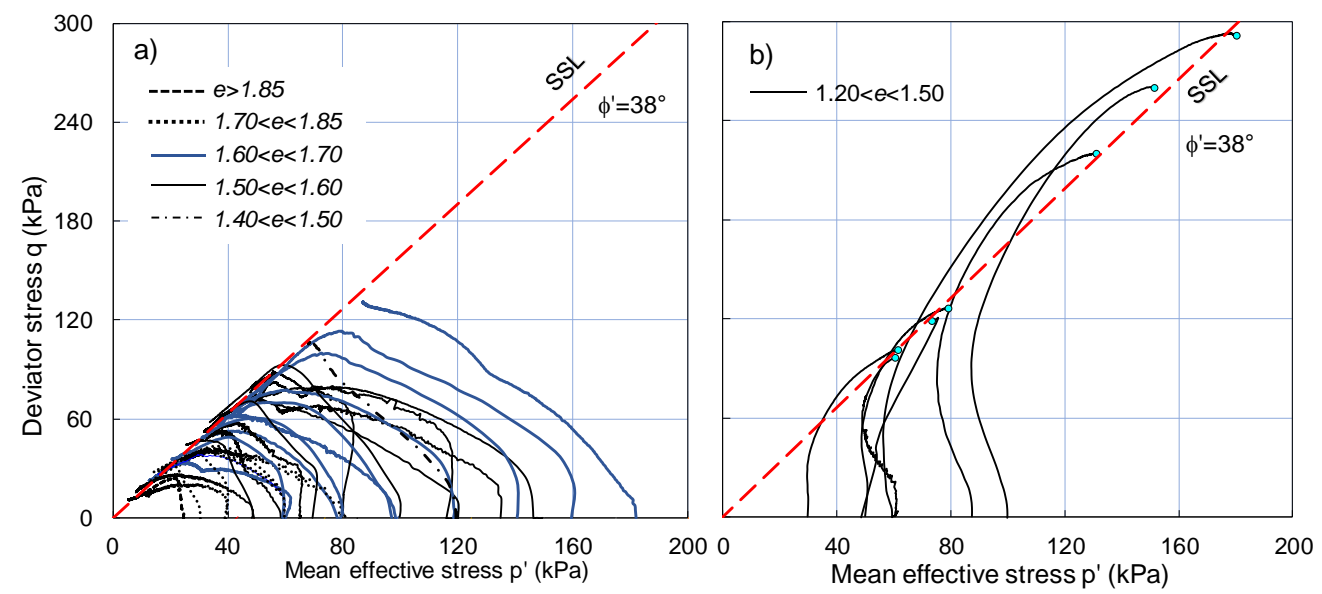

Figure 4. Results of triaxial compression tests on isotropically consolidated specimens (CIU_c tests) on reconstituted specimens of Cervinara ash: (a) brittle response; (b) ductile response.

Another important aspect that emerges from the analysis of such data is that the peak strength is mobilized before reaching the SSL, then the stress path moves to left, while the shear strength is decreasing towards the SSL, approaching it under generally very low mean effective and deviator stresses.

As indicated by Lade and Pradel [20], the envelope of the peak values of very loose granular soils defines an apparently straight line, the so-called instability line (IL), which is located below the SSL. This behavior is clearly shown also by the Cervinara ash-fall. Indeed, in Figure 5 the peak strength of specimens having a void ratio comprised between 1.8-2.0 and between 1.5-1.6 is enveloped by two distinct instability lines ( $\mathrm{IL}_{1}$ and $\mathrm{IL}_{2}$ respectively in Figure 5). According to Chu and Leong [21], the slope of the IL is inversely proportional to the void ratio of the soil at the end of consolidation. Hence, also the width of the zone comprised between the SSL and the IL, the so-called Instability Region, is a function of $e$ : it is as lower in size as lower is the void ratio (Figure 5).

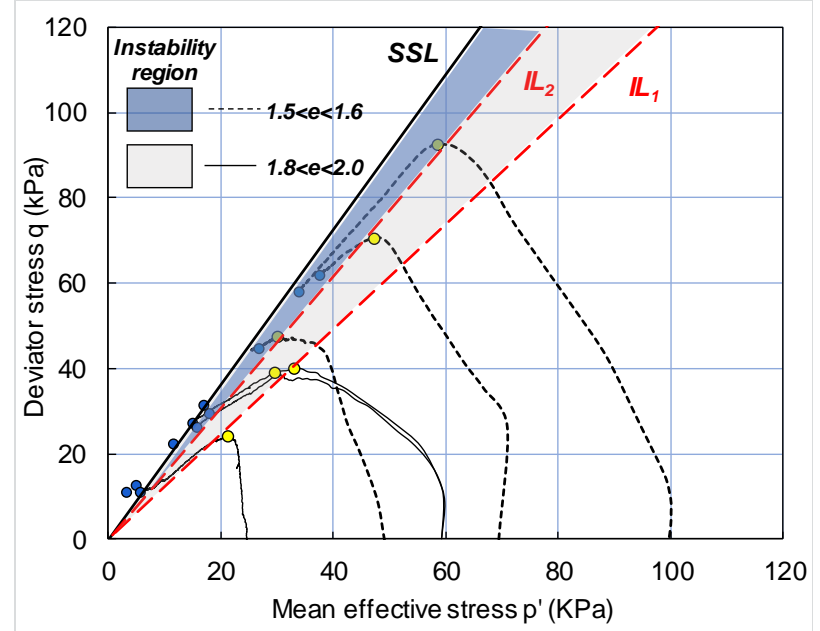

Figure 5. Instability lines and instability regions of specimens with different void ratios. 
As anticipated above, part of the experimental program has been aimed at assessing the influence of different stress histories on the soil response. For this reason, some tests have been carried out on anisotropically consolidated specimens using stress ratios $(\mathrm{K})$ comprising between 0.3 and 0.85 . The results, reported in Figure 6 as a function of the void ratio, are compared to those obtained in CIU_c tests. In the figure, the initial state of stress, the peak and the steady state conditions are indicated by dots. The comparison between CIU_c and CAU_c stress paths suggests that the specimens reach the same steady-state conditions and that, for a given void ratio, the IL is the same regardless of the initial stress conditions. Therefore, the slope of the IL depends on the void ratio at the end of consolidation. In particular, for values of the void ratio of 1.8 or more, it corresponds to a mobilized friction angle of only $29^{\circ}$ or less, which is much lower than the steady-state friction angle. These data suggest that sloping natural soil deposits, which after full saturation, were subjected to a state of stress falling in this zone, might rapidly lose their shear strength as a result of any, even a small, disturbance.
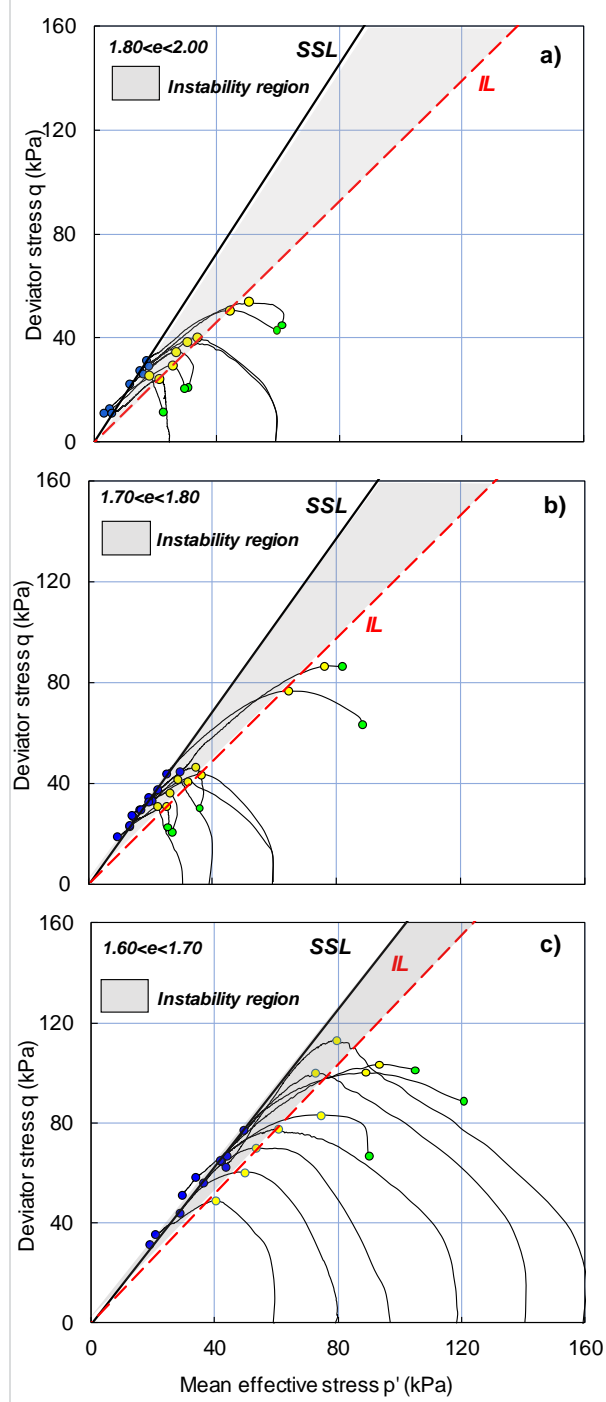

Figure 6. Stress paths of triaxial compression tests on anisotropically consolidated specimens (CAU_c) and CIU_c tests having void ratios ranging between: (a) 1.8-2.0; (b) 1.7-1.8; (c) 1.6-1.7.

The last part of the experimental program, aimed at investigating the influence on the undrained shear strength of the stress path to failure, consisted in undrained extension tests on isotropically consolidated specimens (CIU_e, Table 1). The results of such tests are reported in Figures 7 and 8; in the latter figure they are compared to the results of the CIU_c series. 


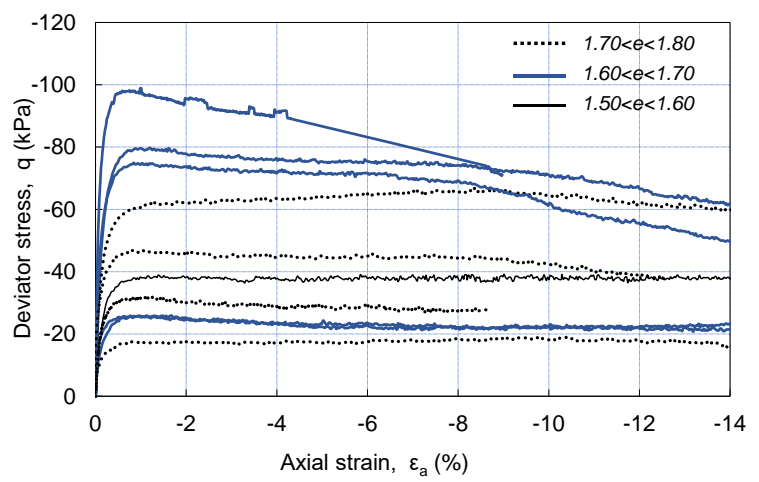

Figure 7. Stress-strain curves in extension tests (CIU_e).

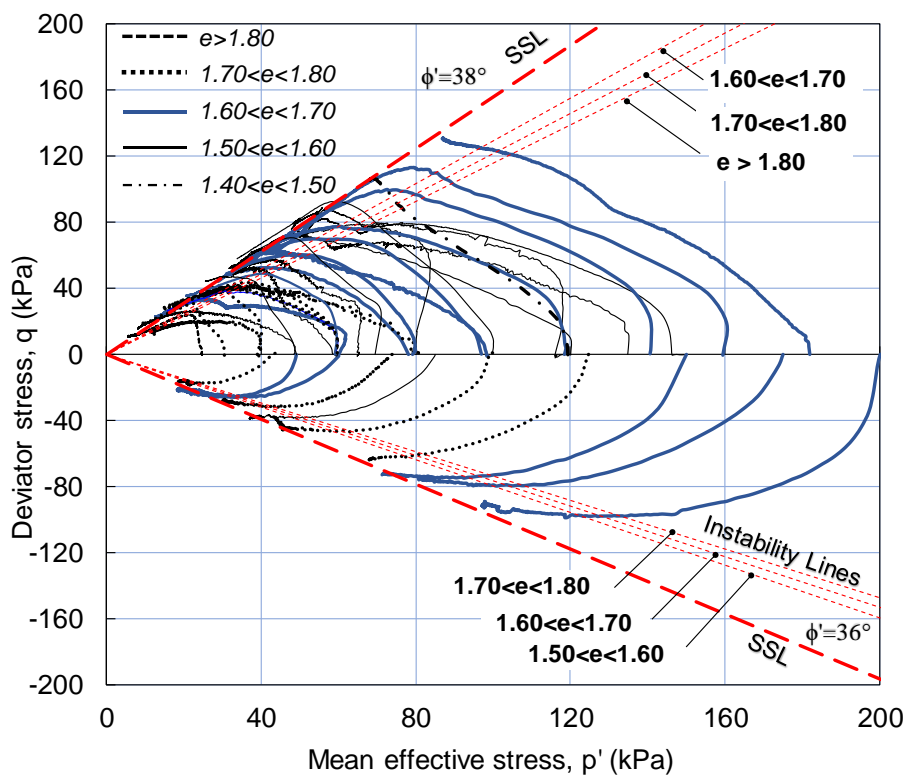

Figure 8. Stress paths in compression and extension tests.

The figures highlight the following points:

- due to the role of the intermediate principal stress, which in CIU_c tests is equal to the minor principal stress and in CIU_e tests is equal to the major principal stress, the slope $M_{e}$ of the SSL in the CIU_e tests is less than the slope $M_{\mathcal{c}}$ in CIU_c tests. As shown in Figure 8, in this case the difference between $M_{c}$ and $M_{e}$ is even higher than the theoretical value since the friction angle measured in extension tests $\left(\varphi_{e}^{\prime}=36^{\circ}\right)$ is slightly less than the value obtained in compression tests $\left(\varphi^{\prime}{ }_{c}=38^{\circ}\right)$;

- instability lines result also from the stress paths obtained in triaxial extension tests; in this case too, the slope of the IL depends on the void ratio.

Commenting on the results of similar data obtained by Ladd and Varallyay [22] on Boston Blue Clay, Leroueil and Hight [23] stressed that, for the same initial consolidation stress, the value of $p^{\prime}$ at failure was similar regardless of the imposed stress path. Therefore, since the slope of the SSL in the stress-plane evaluated in extension, $M_{e}$, is lower than the corresponding in compression, $M_{c}$, the undrained shear strength in extension should be lower than in compression. Based on Figure 8, the same conclusions could be drawn also in the case at hand; in particular, accounting for the different friction angle, the ratio between the undrained strength in extension and in compression should be:

$$
\frac{M_{e}}{M_{c}}=\frac{6 \sin \varphi_{e}^{\prime}}{3+\sin \varphi_{e}^{\prime}} \frac{3-\sin \varphi_{c}^{\prime}}{6 \sin \varphi_{c}^{\prime}}=0.63
$$


In a landslide soil mass, depending on the selected point along the slope, type of movement, interaction between soil mass and constraint (bedrock, etc.), the stress paths to failure can be very different from each other and can significantly differ from those applied in compression triaxial tests [24]. This should be kept in mind when analyzing problems of failure in undrained conditions, not trusting exclusively in the value that is provided by "ordinary" triaxial compression tests if the shear strength in extension is lower than in compression.

The results of all tests, including those obtained on undisturbed samples (Figure 3), have been plotted in the compression plane too (Figure 9), where the ICL (isotropic consolidation line) of the soil has been reported also [11]. As is well known, a prediction of the soil response (ductile or brittle) to undrained shearing may be obtained accounting for the position of the point that represents the initial soil state, with respect to the SSL.

The experimental results show that the SSL of the Cervinara ash is unique, regardless of the type of test. Also, by contrast with results obtained by other scholars on sands $[25,26]$ at least for the selected values of the mean effective stress, the SSL in the compression plane is a straight line.

As shown, the scatter of void ratios for the same value of $p^{\prime}$ comprises the range $+/-0.1$. This might be due to different causes, such as the difficulty in reproducing the same grain size for each specimen and errors in the reconstitution technique or in the measurement of the void ratio.

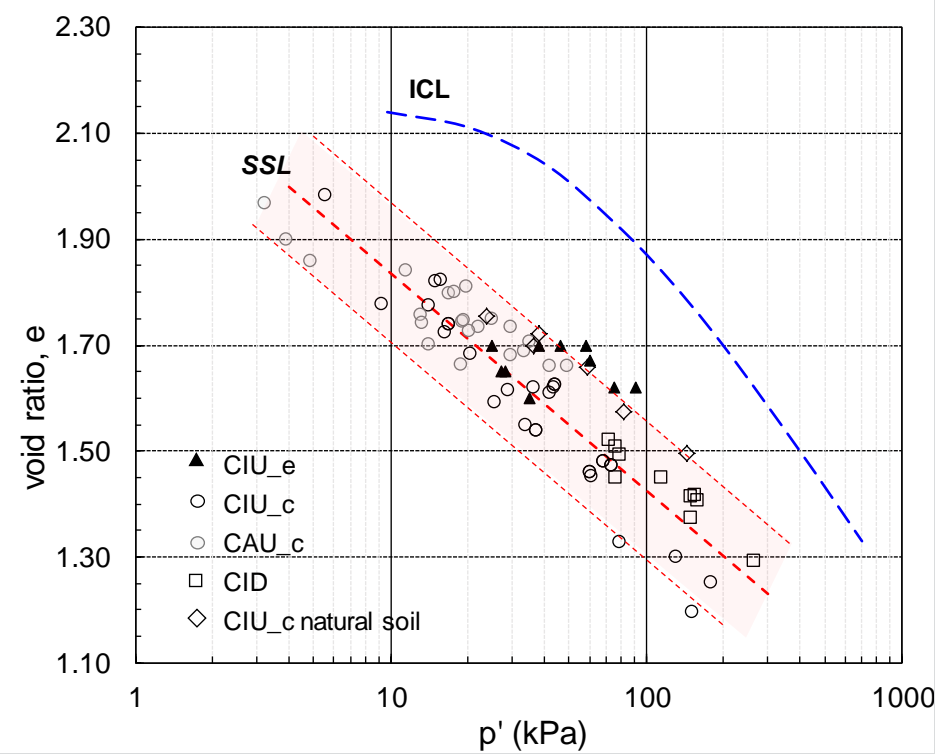

Figure 9. Steady state conditions of the specimens of Cervinara ash in the compression plane.

A useful conclusion which may be drawn from such data is that, for effective confining stresses comparable to the average values which would be operative in the field after full saturation (i.e., for covers of 2-3 m of thickness and stresses up to 30-45 kPa), the threshold of the void ratio above which the undrained soil response is brittle is 1.55-1.65 (Figure 9). As discussed above, the natural void ratio of air-fall volcanic ashes in Campania is generally higher than such values and this is consistent with historic data about landslides in these materials, which are generally of the flow type [27,28].

\section{Conclusions}

A wide area of Campania is mantled by unsaturated pyroclastic soils, which are stable even on steep slopes thanks to suction. However, experience shows that intense and prolonged precipitations can trigger landslides, which often turn into large and destructive flows [29,30]. Mechanisms of undrained instability due to the build up of high positive excess pore pressures have been recognized to be the cause of such events. 
An experimental program consisting in undrained triaxial tests on saturated specimens isotropically and anisotropically consolidated at different values of the void ratio demonstrates that soil specimens having a void ratio similar to the field value display a brittle response causing a significant drop in deviator stress: the position of the SSL in the compression plane may be used as a discriminator of the expected soil response.

The tests also allowed an instability region to be recognized, located between the SSL and the so called instability line. The slope of the latter depends on the void ratio of the soil being inversely proportional to it. This suggests that sloping natural soil deposits subjected to a natural state of stress falling in this zone may rapidly lose their shear strength as a result of any disturbance, such as vibrations, impacts, local failures, turning into rapid and destructive flow-like landslides.

Finally, the experimental program has shown that the undrained strength in extension tests is even less than the undrained strength in ordinary compression tests, highlighting the influence of the stress-path on the mechanical response to failure.

Author Contributions: Conceptualization, L.P., E.D. and L.O.; Data curation, E.D, L.O., S.L. and R.D.; Methodology, L.O.; Validation, L.O.; Writing-original draft, L.P.; Writing-review and editing, L.O. and E.D. All authors have read and agreed to the published version of the manuscript.

Funding: This research was carried out with the support of the project PRIN 2015 "Innovative monitoring and design strategies for sustainable landslide risk mitigation" No. 201572YTLA, funded by the Italian Ministry of Education, University and Research and with the support of the project VALERE: VAnviteLli pEr la RicErca (V:ALERE 2019 founded by University of Campania "Luigi Vanvitelli").

Acknowledgments: The authors acknowledge the anonymous reviewers for their useful suggestions.

Conflicts of Interest: The authors declare no conflict of interest.

\section{References}

1. Anderson, S.A.; Sitar, N. Analysis of rainfall-induced debris flow. J. Geotech. Eng. 1995, 121, 544-555. [CrossRef]

2. Sassa, K. Mechanism of flows in granular soils. In Proceedings of the GeoEng 2000, an International Conference on Geotechnical \& Geological Engineering, Melbourne, Australia, 19-24 November 2000; pp. 1671-1702.

3. Zhang, D.; Wang, G.; Luo, C.; Chen, J.; Zhou, Y. A rapid loess flowslide triggered by irrigation in China. Landslides 1995, 6, 55-60. [CrossRef]

4. Sladen, J.A.; D'Hollander, R.D.; Krahn, J. The liquefaction of sand, a collapse surface approach. Ca. Geotech. J. 1985, 22, 564-578. [CrossRef]

5. Wang, G.; Sassa, K. Factors affecting rainfall-induced flowslides in laboratory flume tests. Gèotechnique 2001, 51, 587-599. [CrossRef]

6. Olivares, L.; Damiano, E. Postfailure mechanics of landslides: Laboratory investigation of flowslides in pyroclastic soils. J. Geotech. Geoenv. Eng. 2007, 133, 51-62. [CrossRef]

7. Damiano, E.; Olivares, L. The role of infiltration processes in steep slopes stability of pyroclastic granular soils: laboratory and numerical investigation. Nat. Hazards 2010, 52, 329-350. [CrossRef]

8. Cascini, L.; Guida, D.; Nocera, N.; Romanzi, G.; Sorbino, G. A preliminary model for the landslides of May 1998 in Campania Region. Proceedings of 2nd International Symposium on Geotechnics of Hard Soil Soft Rock, Naples, Italy, 12-14 October 1998; pp. 1623-1649.

9. Fiorillo, F.; Guadagno, F.M.; Equino, S.; De Blasio, A. The December 1999 Cervinara landslides: further debris flows in the pyroclastic deposits of Campania (southern Italy). Bull. Eng. Geol. Environ. 2001, 60, 171-184. [CrossRef]

10. Calcaterra, D.; Santo, A. The January 10, 1997 Pozzano landslide, Sorrento peninsula, Italy. Eng. Geol. 2004, 75, 175-200. [CrossRef]

11. Picarelli, L.; Evangelista, A.; Rolandi, G.; Paone, A.; Nicotera, M.V.; Olivares, L.; Scotto di Santolo, A.; Lampitiello, S.; Rolandi, M. Mechanical properties of pyroclastic soils in Campania Region. In Proceedings of the 2nd International Workshop on Characterisation and Engineering Properties of Natural Soils, Singapore, 29 November-1 December 2006; pp. 2331-2384. 
12. Shoji, S.; Nanzyo, M.; Dahlgren, R.A. Volcanic Ash Soils: Genesis, Properties and Utilization; Elsevier Science Publishers B.V.: Amsterdam, The Netherlands, 1993.

13. Lampitiello, S. Resistenza non drenata e suscettività alla liquefazione di ceneri vulcaniche della Regione Campania. Ph.D. Thesis, Seconda Università di Napoli, Aversa, Italy, April 2004.

14. Bilotta, E.; Cascini, L.; Foresta, V.; Sorbino, G. Geotechnical characterisation of pyroclastic soils involved in huge flowslides. Geotech. Geol. Eng. 2005, 23, 365. [CrossRef]

15. Nicotera, M.V.; Papa, R.; Urciuoli, G. The hydro-mechanical behaviour of unsaturated pyroclastic soils: An experimental investigation. Eng. Geol. 2015, 195, 70-84. [CrossRef]

16. Hunter, G.; Fell, R. Mechanics of failure of soil slopes leading to "rapid" failure. In Proceedings of the International Conference on Fast Slope Movements Prediction and Prevention for Risk Mitigation, Napoli, Italy, 11-13 May 2003; pp. 283-290.

17. Olivares, L.; Picarelli, L. Susceptibility of loose pyroclastic soils to static liquefaction: Some preliminary data. In Proceedings of the International Conference on Landslides-Causes, Impacts and Countermeasures, Davos, Switzerland, 17-21 June 2001; pp. 75-85.

18. Olivares, L.; Damiano, E.; Netti, N.; De Cristofaro, M. Geotechnical Properties of Two Pyroclastic Deposits Involved in Catastrophic Flowslides for Implementation in Early Warning Systems. Geosciences 2019, 9, 24. [CrossRef]

19. Suits, L.; Sheahan, T.C.; Frost, J.; Park, J.-Y. A Critical Assessment of the Moist Tamping Technique. Geotech. Testing J. 2003, 26. [CrossRef]

20. Lade, P.V.; Pradel, V. Instability and plastic flow of soils. Experimental observation. J. Geotech. Eng. Division ASCE 1990, 116, 2532-2550. [CrossRef]

21. Chu, J.; Leong, W.K. Effect of fines on instability behaviour of loose sand. Géotechnique 2002, 52, 751-755. [CrossRef]

22. Ladd, C.C.; Varallyay, J. The Influence of Stress System on the Behaviour of Saturated Clays during Undrained Shear; Research in Earth Physics Phase. Rep. n. 1, Part II, Report R65-11; Massachusetts Institute of Technology: Cambridge, MA, USA, 1965; p. 263.

23. Leroueil, S.; Hight, D.H. Characterisation of soils for engineering purposes. In Proceedings of the Second Internatinal Symposium Characterisation and Engineering Properties of Natural Soils, Singapore, 29 November-1 December 2006; pp. 29-254.

24. Darban, R.; Damiano, E.; Minardo, A.; Olivares, L.; Picarelli, L.; Zeni, L. An Experimental Investigation on the Progressive Failure of Unsaturated Granular Slopes. Geosciences 2019, 9, 63. [CrossRef]

25. Been, K.; Jefferies, M.G.; Hackey, J. The critical state of sands. Geotechnique 1991, 41, 365-381. [CrossRef]

26. Murthy, T.G.; Loukidis, D.; Carraro, J.A.H.; Prezzi, M.; Salgado, R. Undrained monotonic response of clean and silty sands. Geotechnique 2007, 57, 273-288. [CrossRef]

27. Picarelli, L.; Olivares, L.; Avolio, B. Zoning for flowslide and debris flow in pyroclastic soils of Campania Region based on "infinite slope" analysis. Eng. Geol. 2008, 102, 132-141. [CrossRef]

28. Olivares, L.; Picarelli, L. Modelling of flowslides behaviour for risk mitigation. In Proceedings of the 6th International Conference on Physical Modelling in Geotechnics, Hong Kong, China, 4-6 August 2006; pp. 99-112.

29. Olivares, L.; Damiano, E.; Mercogliano, P.; Picarelli, L.; Netti, N.; Schiano, P.; Savastano, V.; Cotroneo, F.; Manzi, M.P. A simulation chain for early prediction of rainfall-induced landslides. Landslides 2014, 11, 765-777. [CrossRef]

30. Damiano, E.; Mercogliano, P.; Netti, N.; Olivares, L. A "simulation chain" to define a Multidisciplinary Decision Support System for landslide risk management in pyroclastic soils. Nat. Hazards Earth Syst. Sci. 2012, 12, 989-1008. [CrossRef]

(C) 2020 by the authors. Licensee MDPI, Basel, Switzerland. This article is an open access article distributed under the terms and conditions of the Creative Commons Attribution (CC BY) license (http://creativecommons.org/licenses/by/4.0/). 